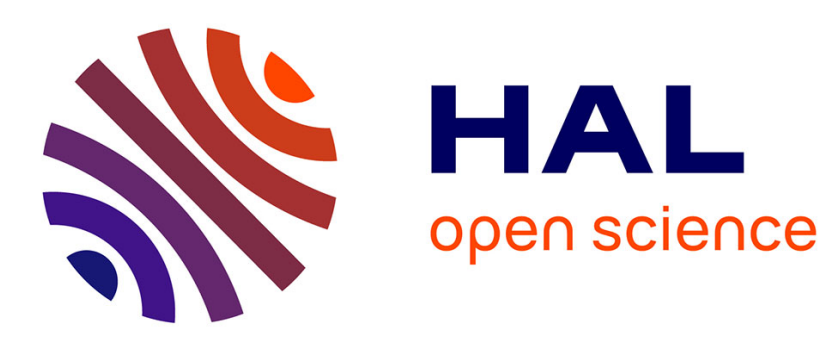

\title{
Enhanced growth of wild cherry using micropropagated plants and mycorrhizal inoculation
}

P.E. Lovato, A. Trouvelot, V. Gianinazzi-Pearson, S. Gianinazzi

\section{To cite this version:}

P.E. Lovato, A. Trouvelot, V. Gianinazzi-Pearson, S. Gianinazzi. Enhanced growth of wild cherry using micropropagated plants and mycorrhizal inoculation. Agronomy for Sustainable Development, 2006, 26 (3), pp.209-213. hal-00886347

\section{HAL Id: hal-00886347 https://hal.science/hal-00886347}

Submitted on 1 Jan 2006

HAL is a multi-disciplinary open access archive for the deposit and dissemination of scientific research documents, whether they are published or not. The documents may come from teaching and research institutions in France or abroad, or from public or private research centers.
L'archive ouverte pluridisciplinaire HAL, est destinée au dépôt et à la diffusion de documents scientifiques de niveau recherche, publiés ou non, émanant des établissements d'enseignement et de recherche français ou étrangers, des laboratoires publics ou privés. 


\title{
Enhanced growth of wild cherry using micropropagated plants and mycorrhizal inoculation
}

\author{
P.E. Lovato*, A. Trouvelot, V. GianinazZi-Pearson, S. GianinazZI \\ Centro de Ciências Agrárias, Universidade Federal de Santa Catarina, C.P. 476 88040-970 Florianópolis SC, Brazil
}

(Accepted 24 July 2006)

\begin{abstract}
Mycorrhizal inoculation is a promising, sustainable technique to enhance plant growth. We evaluated the effects of mycorrhizal inoculation and of the use of two substrates, soil and peat, on the growth of wild cherry, Prunus avium L., on the weaning and post-weaning. After weaning, plants were grown for 13 weeks in a greenhouse on either $40 \%$ soil or $40 \%$ peat at two levels of fertiliser: 2 or $4 \mathrm{~g} \mathrm{~m}^{-3}$ of a 16:9:12 slow-release fertiliser. They were subsequently kept for a further 120 days in a frost-free greenhouse before outplanting to the field. The results show that enhanced plant growth after seven months in the field was associated with increased peat and fertiliser levels in the substrates during the post-weaning growth phase, and with prior mycorrhizal inoculation by a $G$. deserticola isolate, which compensated for less favourable substrate conditions. Plants inoculated with $G$. intraradices had more branches positioned in the lower half of the stem, while plants inoculated with $G$. deserticola had more branches in the upper half of the stem.
\end{abstract}

arbuscular mycorrhiza / plant architecture / wild cherry / field outplanting

\section{INTRODUCTION}

Microbial inoculation is a promising, sustainable technique to enhance plant growth (e.g. Rodríguez-Romero et al., 2005; Barneix et al., 2005; Fauzia et al., 2006). Production of micropropagated plants is one of the most promising fields for application for arbuscular mycorrhizal fungus (AMF) inoculation (Lovato et al., 1996; Azcón-Aguilar et al., 1997). Micropropagated plants are produced in axenic conditions and generally weaned in artificial and/or disinfected substrates, therefore requiring reintroduction of the symbiotic fungi for enhanced plant growth, especially in artificial or disinfected soils/substrates (Pons et al., 1983; Saggin and Lovato, 1999), or for protection against root pathogens (Cordier et al., 1996, 1998). There can also be an effect of AMF inoculation on flowering (Scagel, 2004) and root architecture (Azcón-Aguilar et al., 1996; Locatelli et al., 2002), which can have a significant effect on plant yield and quality. Whilst several reports have shown enhanced growth and development of micropropagated plants due to AMF inoculation (Lovato et al., 1996), most of them are restricted to the weaning phase or to very early stages of growth. The few investigations that have been conducted under field conditions (Vestberg, 1992; Siqueira et al., 1997) showed greater growth and yield in mycorrhizal plants, which probably resulted from advantages obtained from AMF inoculation during early growth.
Substrate composition and AMF isolates can differentially determine subsequent development of micropropagated plants (Estaún et al., 1999; Zemke et al., 2003). Concentrations of nutrients, sugar and hormones used during weaning or in the post-weaning periods can also interact with the establishment of the mycorrhizal association (Dutra et al., 1996; Souza et al., 1996). In a previous work, we reported that beneficial effects of mycorrhizal inoculation on growth of micropropagated wild cherry and ash during the weaning phase disappeared when plants were transferred to substrates with fertiliser levels used in commercial nurseries (Lovato et al., 1994). This was probably due to the high levels of nutrients in the growth media. We evaluated interactions between substrate composition and arbuscular mycorrhizal inoculation in wild cherry plants grown under controlled conditions, and their effect on field growth of the same plants in a non-disinfected soil, containing indigenous AMF propagules.

\section{MATERIALS AND METHODS}

Wild cherry (Prunus avium L.) cv. F12/1 plants were micropropagated as previously described (Hammatt and Grant, 1993). Microplants with one or two root primordia were transferred to trays containing a 2:1:1 (v:v:v) mixture of clay loam soil, perlite and gravel (Lovato et al., 1994). The soil, from

\footnotetext{
* Corresponding author: plovato@mbox1.ufsc.br

Present address: S UMR INRA/Université de Bourgogne, BV 1540, 21034 Dijon Cedex, France.
} 
Domaine d'Époisses (Dijon, France) had the following properties: $\mathrm{pH}$ 6.8; $26 \mathrm{~g} \mathrm{~kg}^{-1}$ organic matter; $203 \mathrm{mmol}_{\mathrm{c}} \mathrm{dm}^{-3} \mathrm{CEC}$; $106 \mathrm{mg} \mathrm{kg}^{-1}$ Olsen-P). In mycorrhizal treatments, soil was replaced by soil-based inocula of Glomus intraradices Schenck and Smith (BEG 141), or Glomus deserticola Trappe, Bloss and Menge (BEG 73, supplied by C. Azcón-Aguilar, Zaidin, Spain). Inoculum potential, evaluated by the Most Probable Number Method (MPN), was 6600 (1904-22880) propagules $\mathrm{kg}^{-1}$. Plants were weaned for 21 days in a controlled environment room (12 h/day, $220 \mu \mathrm{mol} \mathrm{m} \mathrm{m}^{-2} \mathrm{~s}^{-2}, 19-22{ }^{\circ} \mathrm{C}, 70 \%$ relative humidity), and then transferred to $2-\mathrm{L}$ pots in a greenhouse (July-October, $19-24{ }^{\circ} \mathrm{C}$, light supplemented to $16 \mathrm{~h}$ a day). Two steam-disinfected substrates and two levels of fertilisation, equivalent to those adopted by nurserymen, were used. One substrate consisted of $40 \%$ clay loam (Époisses) soil (v:v), $20 \%$ commercial-grade black sphagnum peat, $20 \%$ wood chips (Sylvagrest, France) and $20 \%$ gravel, and the other substrate of $20 \%$ clay loam soil (v:v), $40 \%$ peat, $20 \%$ wood chips and $20 \%$ gravel. Fertiliser levels corresponded to 2 and $4 \mathrm{~kg} \mathrm{~m}^{-3}$ of slowrelease fertiliser (Osmocote $®$, Sierra Chemical, The Netherlands) with a final NPK composition of 16:9:12 (1:1 mixture of 3- to 4- and 8-to 9- month release time types). All substrates received $1.5 \mathrm{~kg} \mathrm{~m}^{-3}$ of a $3: 2$ mixture of $\mathrm{CaCO}_{3}$ and $\mathrm{MgCO}_{3}$ and $150 \mathrm{~g} \mathrm{~m}^{-3} \mathrm{NH}_{4} \mathrm{NO}_{3}$.

After 13 weeks, the plants were transferred to a frost-free greenhouse $\left(\mathrm{t}>4{ }^{\circ} \mathrm{C}\right)$. These conditions caused the plants to lose their leaves, and after 120 days they were outplanted, with bare roots, to the field into a non-disinfected clay loam soil (Domaine d'Époisses, INRA-Dijon, France) with 440 (1331452) AMF propagules $\mathrm{kg}^{-1}$, as calculated by the Most Probable Number (MPN) method. By that time the plants had an average height of $1.08 \pm 0.09 \mathrm{~m}$ and an average number of $23 \pm$ 3.5 buds. Plant spacing in the field was $1.0 \mathrm{~m} \times 1.0 \mathrm{~m}$. Treatments were arranged in the field in randomised blocks with five replicates. Plant growth was evaluated by stem length increase and lateral branch extension, in order to determine the effects of the treatments. Total length of branches was recorded separately for the upper half and the lower half of the stems. After 26 weeks, the plants were harvested and stem diameter, total stem and branch length and shoot dry weight were determined. Root samples were cleared and stained (Phillips and Hayman, 1970) and mycorrhizal colonisation was assessed according to Trouvelot and Kough (1986).

Due to the limited number of plants there was an unbalanced design among the factors substrate composition, fertiliser level and inoculation treatments. Therefore, in a first step, each combination of factors was considered as a different qualitative treatment. Data were subjected to ANOVA, and means were compared by the Newman-Keuls test at $P \leq 0.05$. In a second step, data were analysed following an over-parameterised model with type-IV decomposition (http://www.statsoft.com/ textbook/stathome.html), and contrasts were calculated for each factor combination of interest.

\section{RESULTS AND DISCUSSION}

In the field phase, the highest values in shoot dry weight (Tab. I) were attained by wild cherry plants that had been postweaned and overwintered in high-peat, high-fertiliser substrate.
Table I. Shoot dry weight ( $\mathrm{g}$ plant ${ }^{-1}$ ) of field-grown wild cherry plants weaned in substrates with $40 \%$ soil or $40 \%$ peat, with two fertiliser levels, uninoculated (NM) or inoculated with Glomus intraradices $(\mathrm{Gi})$ or $G$. deserticola $(\mathrm{Gd})$.

\begin{tabular}{lcccc}
\hline & & \multicolumn{3}{c}{ Inoculation } \\
\hline Substrate & Fertiliser level & NM & Gi & Gd \\
$40 \%$ soil & low & $578 \mathrm{c}$ & $661 \mathrm{~b}$ & $600 \mathrm{c}$ \\
$40 \%$ peat & low & $668 \mathrm{~b}$ & $639 \mathrm{~b}$ & $727 \mathrm{a}$ \\
$40 \%$ soil & high & $657 \mathrm{~b}$ & $644 \mathrm{~b}$ & - \\
$40 \%$ peat & high & $725 \mathrm{a}$ & $725 \mathrm{a}$ & - \\
\hline
\end{tabular}

* Means followed by different letters are significantly different $(P \leq 0.05)$ as indicated by the Newman-Keuls test; - : treatment non existent.

Plants showed no difference among treatments, in height or leaf numbers during the post-weaning phase, as previously reported (Lovato et al., 1994), and during that stage mycorrhizal colonisation in the inoculated treatments ranged between 70 and $80 \%$. In this experiment, mycorrhizal root colonisation varied between 50 and $60 \%$, with no difference among treatments. Shoot dry weight was increased by previous inoculation with $G$. intraradices in high-soil, low-fertiliser substrate and with $G$. deserticola in the high-peat substrate with low fertiliser level (there were no G. deserticola-inoculated plants in high-fertiliser level substrates). The wild cherry plants priorly inoculated with G. deserticola and grown in the high-peat substrate with the low fertiliser level also had the highest increase in main stem length, attaining a total length of $99 \mathrm{~cm}$, doubling their height after seven months of growth in the field. Plants from all other treatments were $78-91 \mathrm{~cm}$ in height, an increase of between 70 and $90 \%$ by the end of the growing season, with no significant differences among them, but their growth pattern differed among treatments.

Differences in number, size and position of branches in fieldgrown plants were evident (Fig. 1), and were related to the substrate composition and to prior mycorrhizal inoculation in pots. The effects of prior inoculation were more evident in the first three months of growth in the field (i.e., until mid-June), and diminished towards the end of the growth season. In the early phases of field growth, branches appeared earlier in the plants inoculated with $G$. deserticola and $G$. intraradices. However, by the end of the experiment there was still a clear effect of the substrates used during greenhouse growth. Figure 2 shows branch length, as recorded separately for the lower and upper halves of the main stem, with no significant differences between treatments as analysed separately. However, there was a significant effect of substrate composition, as evaluated by contrast calculation. Plants previously grown in substrate with high peat and high fertiliser levels had a significantly larger proportion of total length of branches in the upper position as compared with all other treatments (Tab. II).

Shoot biomass accumulation of micropropagated wild cherry plants after seven months in the field was related to substrate and inoculation conditions during the greenhouse postweaning phase. Higher peat and fertiliser levels in substrates used during the post-weaning phase, and inoculation with $G$. deserticola during the weaning phase enhanced plant growth 


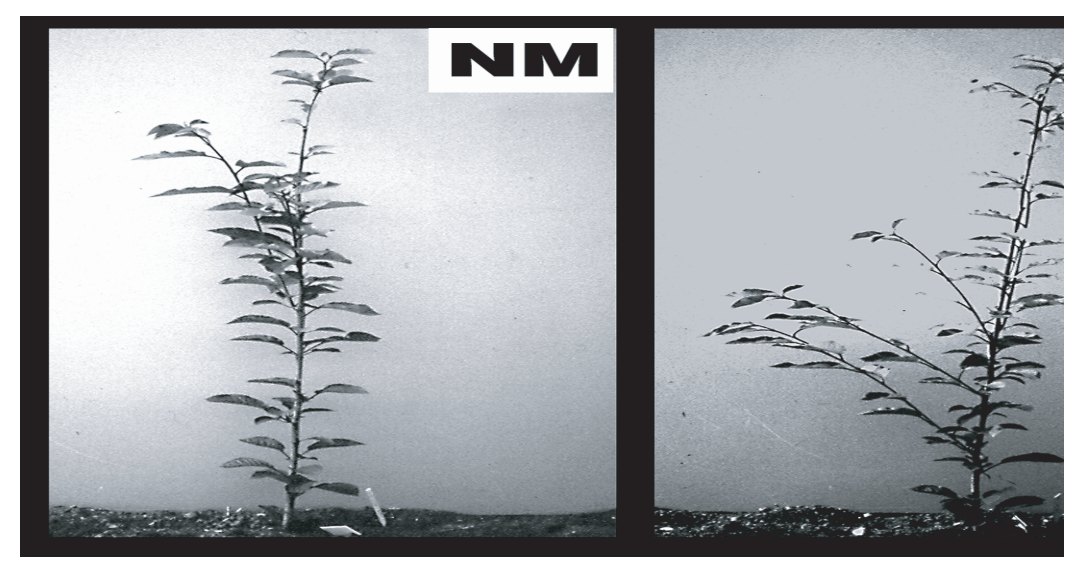

Figure 1. Wild cherry plants after 12 weeks of growth under field condition, uninoculated (NM) or inoculated at the weaning stage with Glomus intraradices $(\mathrm{Gi})$ or Glomus deserticola $(\mathrm{Gd})$. Plants shown are from $40 \%$ soil, low fertilizer substrates.

$40 \%$ soil, low fertilizer

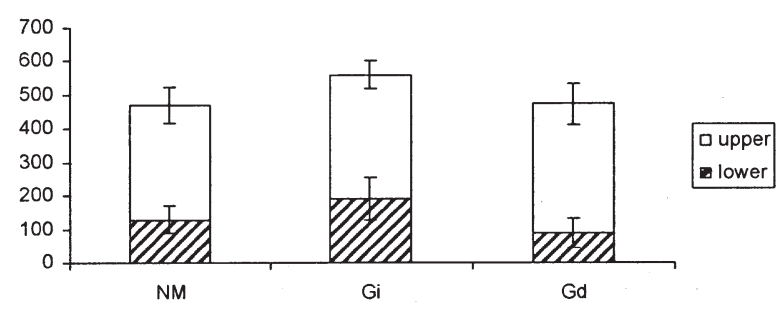

$40 \%$ peat, low fertilizer

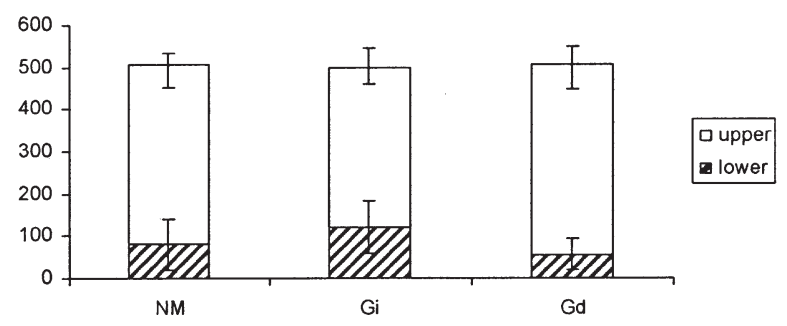

$40 \%$ soil, high fertilizer

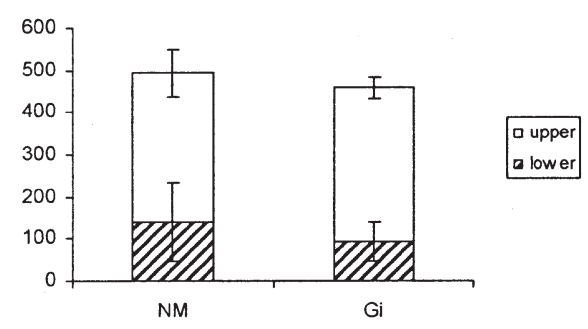

$40 \%$ peat, high fertilizer

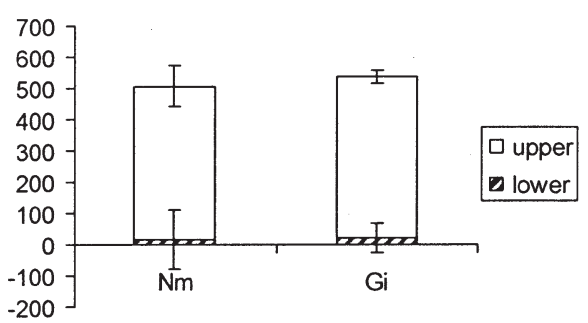

Figure 2. Total length $(\mathrm{cm})$ of lateral branches located in the upper half and in the lower half of the main stem of wild cherry plants non inoculated (NM), or inoculated with Glomus intraradices (Gi) or Glomus deserticola (Gd) grown under field condition after hardening and growth in greenhouse conditions in substrates with $40 \%$ soil or $40 \%$ peat, with low or high level of fertiliser. Mean of five replicates. Bars represent standard errors of the mean.

and development after outplanting to the field. The results suggest an interaction between substrate composition, fertilisation and AMF inoculation, as previously reported for micropropagated woody plants (Estaún et al., 1999), since G. deserticola and $G$. intraradices only improved growth of plants previously cultivated with lower amounts of fertiliser in high- and lowpeat substrates, respectively. Differences in growth promotion of micropropagated plants have been reported for different species of perennial plants (e.g., Monticelli et al., 2000; Taylor and Harrier, 2000; Yano-Melo et al., 1999). Main stem and lateral branch growth was also differentially affected by substrates and AMF inoculation.

Wild cherry plants inoculated with G. deserticola in low-fertiliser substrates had longer length of lateral branches located in their upper parts, a characteristic which can confer higher commercial value upon the plants, whereas plants inoculated with $G$. intraradices had more and longer branches in the lower half of the stem. These differences were evident up to harvesting. The high-peat, high-fertiliser substrate caused non-inoculated and $G$. intraradices-inoculated plants to have more 
Table II. Ratio of low/high position-lateral branch length of fieldgrown wild cherry plants weaned in substrates with $40 \%$ soil or $40 \%$ peat, with low- or high-fertiliser levels, and uninoculated (NM) or inoculated with Glomus intraradices $(\mathrm{Gi})$ or $G$. deserticola $(\mathrm{Gd})$.

\begin{tabular}{lcccc}
\hline & & \multicolumn{3}{c}{ Inoculation } \\
\hline Substrate & Fertiliser level & NM & Gi & Gd \\
$40 \%$ soil & low & $0.51 \mathrm{a}$ & $0.61 \mathrm{a}$ & $0.28 \mathrm{~b}$ \\
$40 \%$ peat & low & $0.18 \mathrm{c}$ & $0.39 \mathrm{~b}$ & $0.13 \mathrm{c}$ \\
$40 \%$ soil & high & $0.62 \mathrm{a}$ & $0.30 \mathrm{~b}$ & - \\
$40 \%$ peat & high & $0.03 \mathrm{~d}$ & $0.04 \mathrm{~d}$ & - \\
\hline
\end{tabular}

* Means followed by different letters are significantly different $(P \leq 0.05)$ as indicated by the Newman-Keuls test; - : treatment non existent.

branches towards the top of the plant, whereas G. deserticolainoculated plants and non-inoculated plants in high-peat, lowfertiliser substrate were in an intermediary position. The variations in plant development could be due to a different hormonal balance caused by the mycorrhizal association, as previously observed (Souza et al., 1996; Shaul-Keinan et al., 2002). Effects of interactions between auxins and AM mycorrhizas on growth have been demonstrated in woody perennial plants (Dutra et al., 1996). Sugar allocation could also be a determinant factor, since the presence of mycorrhizas has been reported to change sugar distribution in micropropagated pear plants (Raparini et al., 1994), where mycorrhizal plants tended to concentrate more sugar in leaves, and later in roots, than nonmycorrhizal ones. Differential allocation and storage of sugars in roots and shoots may affect plant development of mycorrhizal plants (Estaún et al., 1999). The G. deserticola isolate used in this experiment previously showed greater effects on the growth of wild cherry and another woody plant (common ash) in the early stages of plant growth (Lovato et al., 1994), as compared with two other AMF isolates.

It should be emphasised that the effects reported here were evident several months after plants had been removed from the substrates and outplanted, with bare roots, to the same non-disinfected field soil, rich in mycorrhizal fungal propagules (Gianinazzi-Pearson et al., 1985). One possible reason for the differences between inoculated plants after outplanting to the field may be that plants were colonised differentially by the two fungi introduced in the weaning phase, and/or they differed in their ability to compete with the indigenous fungi present in the field soil.

These results indicate that combinations of substrates and AMF inoculation should be judiciously selected for improving micropropagated plant growth after ouplanting, since they showed physiological effects on plants under field conditions.

\section{CONCLUSIONS}

Higher peat and fertiliser levels in substrates used during the post-weaning phase enhance plant growth and development after outplanting to the field. Main stem and lateral branch growth are differentially affected by substrate composition and by AMF inoculation.
Acknowledgements: The $G$. deserticola inoculum was kindly supplied by C. Azcón-Aguilar, Zaidin Agricultural Station, Spain. The authors are thankful to A. Kunze and L.M. Locatelli for assistance with the statistical analyses and to $\mathrm{S}$. Sturmer for valuable discussion of the manuscript.

\section{REFERENCES}

Azcón-Aguilar C., Barea J.M. (1997) Applying mycorrhiza biotechnology to horticulture: significance and potentials, Sci. Hortic. $68,1-$ 24.

Azcón-Aguilar C., Padilla I.G., Encina C.L., Azcón R., Barea J.M. (1996) Arbuscular mycorrhizal inoculation enhances plant growth and changes root system morphology in micropropagated Annona cherimola Mill., Agronomie 16, 647-652.

Effect of rhizobacteria on growth and grain protein in wheat, Barneix A.J., Saubidet M.I., Fatta N., Kade M. (2005) Agron. Sustain. Dev. 25, 505-511.

Cordier C., Pozo M.J., Barea J.M., Gianinazzi S., Gianinazzi-Pearson V. (1998) Cell defense responses associated with localized and systemic resistance to Phytophthora parasitica induced in tomato by an arbuscular mycorrhizal fungus, Mol. Plant Microbe Int. 11, $1017-1028$.

Cordier C., Trouvelot A., Gianinazzi S., Gianinazzi-Pearson V. (1996) Arbuscular mycorrhiza technology applied to micropropagated Prunus avium and to protection against Phytophthora cinnamomi, Agronomie 16, 679-688.

Dutra P.V., Abad M., Almela V., Agustí M. (1996) Auxin interaction with the vesicular-arbuscular mycorrhizal fungus Glomus intraradices Schenck and Smith improves vegetative growth of two citrus rootstocks, Sci. Hortic. 66, 77-83.

Estaún V., Calvet C., Camprubí A., Pinochet J. (1999) Long-term effects of nursery starter substrate and AM inoculation of micropropagated peach $\times$ almond hybrid rootstock GF 677, Agronomie 19, 483-489.

Fauzia Y. Hafeez, Sumera Yasmin, Dini Arianib, Mehboob-ur-Rahmana, Yusuf Zafar, Kauser A. Malik (2006) Plant growth-promoting bacteria as biofertilizer, Agron. Sustain. Dev. 26, 143-150.

Gianinazzi-Pearson V., Gianinazzi S., Trouvelot A. (1985) Evaluation of the infectivity end effectiveness of indigenous vesicular arbuscular fungal populations in some agricultural soils in Burgundy, Can. J. Bot. 63, 1521-1524.

Hammatt N., Grant N.J. (1993) Apparent rejuvenation of mature wild cherry (Prunus avium L.) during micropropagation, J. Plant Physiol. 141, 341-346.

Locatelli L.M., Vitovski C.A., Lovato P.E. (2002) Sistema radicular de porta-enxertos micropropagados de macieira inoculados com fungos micorrízicos arbusculares, Pesqui. Agropecu. Bras. 37, 12391245.

Lovato P.E., Hammatt N., Gianinazzi-Pearson V., Gianinazzi S. (1994) Mycorrhization of micropropagated mature wild cherry (Prunus avium L.) and common ash (Fraxinus excelsior L.), Agr. Sci. Finland 3, 297-302.

Lovato P.E., Gianinazzi-Pearson V., Trouvelot A., Gianinazzi S. (1996) The state of art of mycorrhizas and micropropagation, Adv. Hortic. Sci. 10, 46-52.

Monticelli S., Puppi G., Damiano C. (2000) Effects of in vivo mycorrhization on micropropagated fruit tree rootstocks, Appl. Soil Ecol. $15,105-111$.

Pons F., Gianinazzi-Pearson V., Gianinazzi S., Navatel J.C. (1983) Studies of VA mycorrhizae in vitro: mycorrhizal synthesis of axenically propagated wild cherry (Prunus avium L.), Plant Soil 71, 217-221.

Phillips J.M., Hayman D.S. (1970) Improved procedures for cleaning roots and staining parasitic and vesicular-arbuscular mycorrhizal fungi for rapid assessment of infection, T. Brit. Mycol. Soc. 55, $158-161$. 
Rapparini F., Baraldi R., Bertazza G. (1994) Growth and carbohydrate status of Pyrus communis plantlets inoculated with Glomus sp., Agronomie 16, 653-661.

Rodríguez-Romero A.S., Piñero Guerra M.S., Jaizme-Vega M.C. (2005) Effect of arbuscular mycorrhizal fungi and rhizobacteria on banana growth and nutrition, Agron. Sustain. Dev. 25, 395-399.

Saggin O.J. Jr., Lovato P.E. (1999) Aplicação de micorrizas arbusculares na produção de mudas e plantas micropropagadas, in: Siqueira J.O., Moreira F.M.S., Lopes A.S., Guilherme L.R.L., Faquim V. (Eds.), Inter-relação fertilidade, biologia do solo e nutrição de plantas, Sociedade Brasileira de Ciência do Solo/Ufla, Viçosa, pp. 725-773.

Scagel C.F. (2004) Soil pasteurization and mycorrhizal inoculation alter flower production and corm composition of Brodiaea laxa "Queen Fabiola", Hortscience 39, 1432-1437.

Shaul-Keinan O., Gadkar V., Ginzberg I., Grunzweig J.M., Chet I., Elad Y., Wininger S., Belausov E., Eshed Y., Arzmon N., Ben-Tal Y., Kapulnik Y. (2002) Hormone concentrations in tobacco roots change during arbuscular mycorrhizal colonization with Glomus intraradices, New Phytol. 154, 501-507.

Siqueira J.O., Saggin O.J. Jr., Flores-Aylas W.W., Guimarães P.T.G. (1997) Arbuscular mycorrhizal inoculation and superphosphate application influence plant development and yield of coffee in Brazil, Mycorrhiza 7, 293-300.
Souza P.V.D., Fonfria A., Berjon M.A., Orenga V.A. (1996) Interação entre auxinas de síntese e fungos micorrízicos arbusculares: influência sobre o desenvolvimento vegetativo de plântulas de laranjeira azeda (Citrus aurantium L.), Pesqui. Agropecu. Gaúcha 2, 167-172.

Taylor J., Harrier L. (2000) A comparison of nine species of arbuscular mycorrhizal fungi in the development and nutrition of micropropagated Rubus idaeus L. cv. Prosen (Red Raspberry), Plant Soil 225, 53-61.

Trouvelot A., Kough J.L. (1986) Mesure du taux de mycorhization VA d'un système radiculaire. Recherche de méthodes d'estimation ayant une signification fonctionnelle, in: Gianinazzi-Pearson V., Gianinazzi S. (Eds.), Mycorrhizae: physiology and genetics, CNRS-INRA, Dijon, pp. 217-221.

Vestberg M. (1992) Arbuscular mycorrhizal inoculation of micropropagated strawberry and field observations in Finland, Agronomie 12, 865-867.

Yano-Melo A.M., Saggin O.J. Jr., Lima J.M., Melo N.F., Maia L.C. (1999) Effect of arbuscular mycorrhizal fungi on the acclimatization of micropropagated banana plantlets, Mycorrhiza 9, 119-123.

Zemke J.M., Pereira F., Lovato P.E., Silva A.L. (2003) Avaliação de substratos para inoculação micorrízica e aclimatização de dois portaenxertos de videira micropropagados, Pesqui. Agropecu. Bras. 38, 1309-1315. 